\title{
Impact of Coal Sales on Revenue Sharing Fund and Environment in The South Sumatra Province
}

\author{
Fettymia $^{1}$, Eddy Ibrahim² ${ }^{2}$ Didik Susetyo ${ }^{3}$ \\ ${ }^{1}$ Mining Engineering, Faculty of Engineering, Sriwijaya University, Palembang 30319, \\ ${ }^{2}$ Mining Engineering, Faculty of Engineering, Sriwijaya University, Palembang 30319, \\ ${ }^{3}$ Economics, Faculty of Economics, Sriwijaya University, Palembang 30319
}

\begin{abstract}
Coal prices between 2006-2015 trend was fluctuate but tend to decrease every year and affect regional income, especially South Sumatra Province. Coal prices fluctuation are influenced by several factors, the decline of world oil prices, coal production surplus, and China imports restriction. Coal mining industry also give a direct impact to the environment especially effect to work environment for the company workers and the people environment around mining. The coal mining company absorbs local labor so as to increase local revenues from individual income taxes. This research use quantitative approach using Ordinary Least Square (OLS) analytical method with E-views 7 software. Multiple linier regression technique also applied. The Secondary data is time series of $2006-2015$. The results presented in form of tables, images and narration. From this research can be drawn conclusion that price fluctuations have no effect on regional income, but production sold has an effect on regional income.
\end{abstract}

Keywords: Sale, price, royalty, Personal Income Tax Article 21, and Personal Income Tax Article 25/29

\begin{abstract}
Abstrak (Indonesian)
Harga batubara kurun 2006-2015 mengalami fluktuasi sehingga berpengaruh terhadap pendapatan Provinsi Sumatera Selatan. Fluktuasi harga batubara dipengaruhi oleh beberapa hal yaitu menurunnya harga minyak dunia, adanya kelebihan produksi batubara, dan pembatasan impor batubara oleh Cina. Industri pertambangan batubara memberikan dampak terhadap lingkungan salah satunya tenaga kerja. Perusahaan pertambangan batubara menyerap tenaga kerja lokal sehingga meningkatkan pendapatan daerah dari pajak penghasilan perorangan. Penelitian ini merupakan penelitian kuantitatif dengan metode analisis yang digunakan Ordinary Least Square (OLS) dengan software E-views 7.0. Teknik analisa data secara regresi linier berganda. Data sekunder merupakan time series periode tahun 2006 - 2015. Data dan hasil penelitian disajikan dalam bentuk tabel dan gambar serta narasi untuk menginterpretasikan data tersebut. Dapat disimpulkan fluktuasi harga tidak berpengaruh terhadap pendapatan daerah, tapi produksi terjual berpengaruh terhadap pendapatan daerah.
\end{abstract}

Kata Kunci : Penjualan, harga, royalti, PPh pasal 21, dan PPh Pasal 25/29.

\section{Introduction}

South Sumatra as one of the largest coal producing provinces in Indonesia. The coal mining industry that benefits individuals and businesses affects the environment around where coal mines are located that is absorbing a lot of local labor.The price of Reference Coal in the period of 2011-2015 fluctuating annually affects NonTax Revenue (Natural Resources) such as regional revenue in 2013 amounted to 1.385 Trillion Rupiah and decreased the amount of regional revenue in 2014 amounted to 1.180 Trillion Rupiah. (South Sumatra provincial government, 2014).

Research by Agus Sulaksono (2015) states coal production has a positive effect on the welfare of Indonesian society and positively affect the Gross Regional Income of the mining sector in Indonesia.

Article History:

Received: 12 December 2017

Accepteed: 2 February 2018

DOI: $10.22135 /$ sje.2018.3.1.13-18

*Corresponding Author:fetty_zuhdi@yahoo.co.id
The regions should be able to identify the Revenue Sharing Fund component (Revenue Sharing Fund tax or Natural Resources of Revenue Sharing Fund) which contributes positively and still has the potential to be improved) (Wahyuni and Adi, 2009). Based on the new Income Tax Law (Law no.17 year 2000), starting from the 2001 fiscal year the region obtains a share of personal income tax, namely Income Tax Article 21, which is withholding, employment, service or activity by name of any kind received or obtained by a domestic personal tax payer and income tax article 25/29 namely the amount of tax installment in the current taxable year which must be paid by the taxpayer for each month is the amount of income tax payable according to the Annual Tax Return the income tax of the previous tax year shall be deducted by the withholding income tax as referred to in Article 21 and if the tax payable for a tax year is greater than the tax credit, the underpayment of the tax due shall be settled before the income tax return is filed.

The pur pose of this study is to analyze the fluctuation of coal prices affect the coal sales and analyze the fluctuation of coal sold production affect the regional income of South Sumatra Province.

\section{Method}

The research location is conducted in South Sumatera Province which is a coal producer especially in Mining and Energy Offices, Local Revenue Offices and Central Bureau of Statistics of South Sumatera Province. The research stages as follows; 


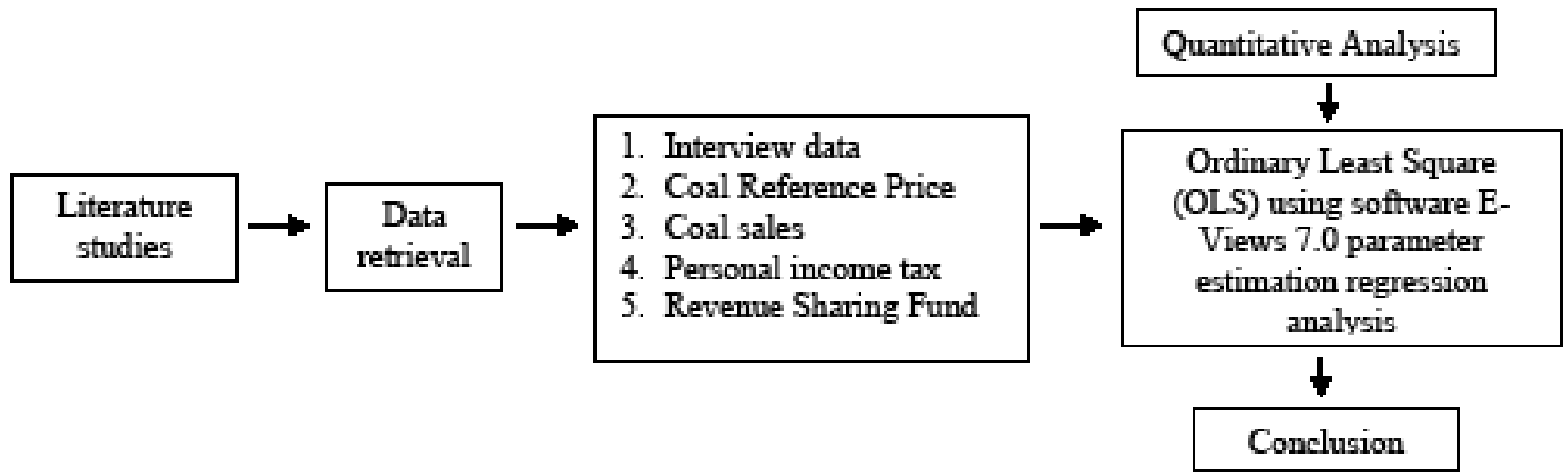

Figure 1. Flow Chart of Research

\section{A. Research Variables}

Personal income tax article 21 and $25 / 29$ variables Personal income tax article 21 and $25 / 29$ is one of the financial sources of the Government of South Sumatera Province. Royalty variable (Revenue Sharing Fund)

The revenue-sharing fund according to Wahyuni and Adi (2009) are funds sourced from State Budget, revenues allocated to the provincial government of south sumatera, based on percentage figures to fund regional needs in the context of decentralization implementation. Revenue Sharing Fund indicators are Revenue Sharing Fund tax and Revenue Sharing Fund non tax (natural resources).

Variable coal price

Price is the most important element in a business entity, with the price of the business entity will benefit. Where in determining the price, there are factors - factors that influence the pricing. Having considered these factors can then be established based on the pricing method (Sunyoto, 2015).

Variable coal sales

From process aspect, production is activity to increase value added (value added) raw material become intermediate goods and finished goods to be sold. And from the aspects of determinants of production which include natural production factors, human resources, capital and technology contribute to the production process (Rasul; Wijiharjono; Setyowati, 2013).

\section{B. Quantitative Analysis}

Quantitative analysis is a test of data analysis related to numbers, and statistical tests. The statistical test is adapted to a careful formulation or identification.

This quantitative analysis will be elaborated in the descriptive analysis of the data. Descriptive analysis is a form of analysis of research data to test generalization of research results based on one sample. This descriptive analysis is done by testing the descriptive hypothesis. The results of the analysis whether the research hypothesis can be generalized or not. If the hypothesis (Ha) is accepted then the results of the study can be generalized. This descriptive analysis uses one or more variables, but is independent. Thus, this analysis is not a comparison or a relationship.

This descriptive analysis is used to explain royalty variables, personal income tax article 21 and 25/29. This descriptive analysis can be tested by using descriptive statistics to give descriptive or descriptive data from the mean, maximum, minimum and standard deviation and can also be seen from the classification of each variable.

\section{Model Parameter Estimation}

In the estimate known term estimator or estimator or decision function. This decision function or estimator is used to obtain estimates for parameters. In this research use Ordinary Least Square (OLS) parameter estimation.

The principle of action is to minimize the number of squares of deviations or errors of observation values against the mean:

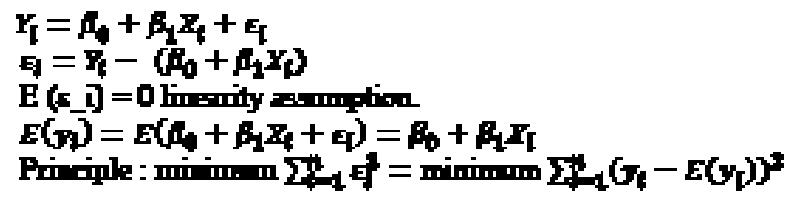

Has 5 assumptions that must be filled by the deviation or error:

Normality : $\varepsilon_{\mathrm{i}} \sim \mathrm{N}\left(0, \sigma^{\wedge} 2\right)$

Error follows normal distribution with average $=0$ and variance $=\sigma 2$

Linierity : $\mathrm{E}(\varepsilon \mathrm{i})=0$.

Linearity shows an average equal to 0 or no correlation between independent variables with error.

Homoscedasticity: $\operatorname{Var}(\varepsilon i)=\sigma 2$

Homoscedasticity shows the variant of the error distribution is either constant or near constant.

Non-Multicollinearity

Multicollinearity shows a linear relationship between some or all of the independent variables that make up the regression model.

Non-autocorrelation: $\operatorname{Cov}(\varepsilon i, \varepsilon j)=0, i \neq j$

Non autocorrelation shows no relationship or correlation between error one with other error.

\section{Regression Analysis}


Linear regression according to Gujarati (2007) is as a study of dependence of one variable, that is variable dependent on one or more other variables or called as explanatory variables with aim to make estimation and or predict mean of population or mean value of variable depends in relation to the known values of the explanatory variable (Sarwono, 2016).

The classical assumption in the regression where the variables on the right in the equation (independent variable) should not be correlated with the disturbance term if this happens then the Ordinary Least Square method (OLS) used to estimate the unknown parameter, the regression coefficient will be biased and inconsistent.

\section{Regression Model}

This method is used to test the hypothesis is multiple linear regression. It is intended to test the price and production content of royalties, Income Tax article 21, Income Tax article 25/29.

\section{The multiple linear regression model is:}

$\mathrm{Y}=\mathrm{a}+\mathrm{b} 1 \mathrm{X} 1+\mathrm{b} 2 \mathrm{X} 2+\mathrm{e}$

Information :

$\mathrm{Y}=$ Local revenue (royalty, Personal income tax article 21 and $25 / 29)$

$\mathrm{a}=$ constants

$\mathrm{b} 1 \mathrm{~b} 2=$ regression coefficient

$\mathrm{X} 1=$ Price

$\mathrm{X} 2=$ Coal sales

$\mathrm{e}=$ other factors (intruder factor)

the multiple linear regression equation should be BLUE (Best Linier Unbias Estimator), meaning that decision making through " $t$ test" and "F test" should not be biased.

\section{Classic Assumption Test}

Multiple linear regression testing can be done after testing the classical assumption to determine whether the data will be used free of classical assumptions or not.

\subsection{Normality Test}

This test is performed to see that a data is normally distributed or not. The residual normality test of the OLS method can be formally detected from the method developed by Jarque-Bera (J-B). Detection by looking at the Jarque-Bera test which is an asymptosis (large sample and based on residual OLS). The statistical test of J-B uses skewness and kurtosis calculations. With the formula as follows:

Where $\mathrm{S}=$ skewness coefficient and $\mathrm{K}=$ kurtosis coefficient. If the variables are distributed normally the coefficients $\mathrm{S}=0$ and $\mathrm{K}=3$. If the residual is normally distributed then the J-B statistic value will be equal to zero (Gujarati, 2007).

Hypothesis testing

H0: the data is not normal

Ha: normal data

Eviews 7.0 output is as follows (Sarwono, 2016)

i.) If JBtest probability is greater $\alpha 5 \%=$ normal distributed data (reject $\mathrm{H} 0$, accept $\mathrm{Ha}$ )

ii.) If the probability of JBtest is smaller $\alpha 5 \%=$ the data is not normally distributed (accept $\mathrm{H} 0$, reject $\mathrm{Ha}$ )

\subsection{Multicollinearity Test}

This test is needed to determine whether there are any independent variables that have similarities with other independent variables in a model (Nugroho 2005). In addition, the detection of multicollinierity also aims to avoid bias in the decision-making process regarding the effect on the partial test of each independent variable to the dependent variable. Detection of multicolonierity in a model can be known if the value of variance inflation factor (VIF) is not more than 10 and tolerance value is not less than 0.1 , then the model can be said freed from multicollinierity whereas VIF $=1 /$ tolerance, if $\mathrm{VIF}=10$ then tolerance $=1 / 10=0.1$.

\subsection{Autocorrelation Test}

The Probability F can also be called the Probability F value. The value of Probability $\mathrm{F}$ arithmetic is greater than alpha level 0.05 so that based on hypothesis test, $\mathrm{H} 0$ accepted which means no autocorrelation occurs, on the contrary, if the probability value of $\mathrm{F}$ arithmetic is less than 0.05 then it can be concluded there is autocorrelation.

\subsection{Test Heteroscedasticity}

The test aims to test whether in the regression model there is a variance inequality, from one observation's residual to another. If the variance of the residual one observation to another observation remains, then it is called Homoscedasticity and if different it is called heteroscedasticity. A good regression model is homoscedasticity or heteroscedasticity.

The basis of decision making with the Glesjer Test is to regress the absolute value of the residual to the independent variable with the regression equation $\mathrm{Ut}=\alpha+\beta \mathrm{Xt}+\mathrm{vt}$ and if the probability level of significance is above the $5 \%$ confidence level $(\alpha=0,05)$, it can be concluded that the regression model does not contain any heteroscedasticity.

\subsection{Statistical test $\boldsymbol{F}$}

The test is used to determine whether the independent variables together influence the dependent variable. This test can be seen if $\mathrm{R}$ squared $<$ error rate (alpha 5\%), then Ha rejected means there is no influence between local revenue variables on price and production sold. Conversely if R squared <error rate (alpha 5\%), then Ha is accepted means there is influence between regional income variable on price and production sold.

\subsection{Statistical t Test}

Partial test is used to determine the influence of each independent variable to the dependent variable. This test can be seen if $t$ arithmetic $<\mathrm{t}$ table, then Ha rejected means there is no influence between regional income variable on price and production sold. Conversely, if $\mathrm{t}$ arithmetic $>\mathrm{t}$ table, then Ha accepted means there is influence between regional income variable on price and production sold.

\subsection{Coefficient Of Determination}

The coefficient of determination $\left(\mathrm{R}^{2}\right)$ is used to determine the extent to which the contribution of independent variables to the dependent variable in the presence of multiple linear regression. If $\mathrm{R}^{2}$ obtained 
Table 1. Sales value (million tons), royalty, personal income tax article 21 (PPh 21), personal income tax article 25/29 [PPh 25/29 (rupi ah)], price (USD) and exchange rate (rupiah) for South Sumatera Province 2006 - 2015

\begin{tabular}{|c|c|c|c|c|c|c|}
\hline Years & Sales & Royalty & PPh 21 & PPh 25/29 & $\begin{array}{c}\text { Coal Reference } \\
\text { Price }\end{array}$ & $\begin{array}{c}\text { Exchange } \\
\text { rate }\end{array}$ \\
\hline 2006 & 925 & 104.037 .000 .000 & 42.392 .000 .000 & 4.786 .000 .000 & 130 & 9300 \\
\hline 2007 & 9.276 .000 & 90.180 .000 .000 & 50.267 .000 .000 & 1.712 .000 .000 & 90 & 9300 \\
\hline 2008 & 10.310 .000 & 125.488 .500 .000 & 58.032 .000 .000 & 1.881 .000 .000 & 119,36 & 9100 \\
\hline 2009 & 10.869 .000 & 404.500 .000 .000 & 66.278 .000 .000 & 4.178 .000 .000 & 70,7 & 9400 \\
\hline 2010 & 15.365 .000 & 397.091 .000 .000 & 85.849 .000 .000 & 5.069 .000 .000 & 91,74 & 10000 \\
\hline 2011 & 20.020 .000 & 414.470 .000 .000 & 103.891 .000 .000 & 4.879 .000 .000 & 118,4 & 8700 \\
\hline 2012 & 25.302 .000 & 564.325 .000 .000 & 125.726 .000 .000 & 5.129 .000 .000 & 95,48 & 9000 \\
\hline 2013 & 24.005 .000 & 980.072 .500 .000 & 129.918 .000 .000 & 3.753 .000 .000 & 82,92 & 9600 \\
\hline 2014 & 27.004 .000 & 1.795 .717 .000 .000 & 141.506 .000 .000 & 3.510 .000 .000 & 72,62 & 11600 \\
\hline 2015 & 20.411 .000 & 204.209 .700 .000 & 152.192 .000 .000 & 4.936 .000 .000 & 60,13 & 11900 \\
\hline
\end{tabular}

close to 1 then it can be said the stronger the model explains the independent variable to the dependent variable.

\section{Results and Discussions}

Table below shown the result of data collection from Mining and Energy Offices, Local Revenue Offices and Central Bureau of Statistics of South Sumatera Province, Indonesian bank and Ministry of mining.

Data input in Eviews 7.0 and results as follows:

1. Tests for dependent variables: coal sales, independent variables: price and exchange rate.

\section{a. Normality test}

JB 1.085632 statistical value with probability $>\alpha=5 \%$ that is 0.581109 results, the data is normally distributed.

\section{b. Test Multicollinearity}

The VIF value for the price and exchange rate variables equals 1.9. Both VIF values of the two variables do not exist $>10$, the result does not occur Multicollinearity in the two independent variables.

\section{c. Test autocorrelation}

Probability Value $F(2,5)$ or $F$ arithmetic of 0.0870 . Probability Value $\mathrm{F}$ arithmetic > alpha $0.05(5 \%)$, based on the hypothesis test, $\mathrm{H} 0$ is accepted which means no autocorrelation occurs.

\section{d. Test heteroscedasticity}

Value Probability F arithmetic of $0.0931>$ alpha 0.05 (5\%), based on hypothesis test $\mathrm{H} 0$ accepted which means no heteroscedasticity occur.

\section{e. $F$ test and $t$ test}

The result of the F test is $\mathrm{R}$ squared: $0.1950>$ alpha $0,05=$ the model is estimated feasible.Result of $t$ test show free variable that is price with result $\mathrm{t}$ arithmetic $=-0,474136$ while $\mathrm{t}$-table 1,41492 .
The value of $t$ arithmetic $<t$ table statistically the price variable has no effect on the production variable sold.

\section{f. Coefficient of determination}

The value of $\mathrm{R}$ squared is 0.1950 , then 19.5 percent of the independent variables can explain the dependent variable, the remaining 80.5 percent is explained by the variable outside the model. Price variables do not have a significant influence on sales variables.

2. Tests for dependent variables: coal sales, independent variables: royalties, prices and exchange rates.

\section{a. Normality test}

JB statistical value of 0.841350 with probability $0.656603>\alpha=$ $5 \%$, the result of data is normally distributed.

\section{b. Test Multicollinearity}

The VIF value for the royalty variable $(1,2)$, the price $(2.0)$ and the exchange rate $(2,1)$ of the three variables no greater than 10 , the result does not occur Multicollinearity in the three independent variables.

\section{c. Test Autocorrelation}

Probability Value F $(2,5)$ or F arithmetic of 0.1536 . Probability Value $\mathrm{F}$ arithmetic $>$ alpha $0.05(5 \%)$, based on the hypothesis test, $\mathrm{H} 0$ is accepted which means no autocorrelation occurs.

\section{d. Test Heteroscedasticity}

Value Probability F arithmetic of $0.6469>$ alpha 0.05 (5\%), based on hypothesis test $\mathrm{H} 0$ accepted which means no heteroscedasticity occur.

\section{e. F test and $t$ Test}

The result of the F test is R squared: $0.7183>$ alpha $0.05=$ the mod$\mathrm{el}$ is estimated to be feasible. Result of $\mathrm{t}$ test show independent vari- 
able that is royalty with result $\mathrm{t}$ arithmetic $=3.341156$ while $\mathrm{t}$-table 1.94318. Result of $\mathrm{t}$ test, $\mathrm{t}$ arithmetic $>\mathrm{t}$ table which statistically royalty variable influence to sales variable. This can be because if high coal sales will add royalty income.

\section{f. Coefficient of Determination}

The value of $\mathrm{R}$ squared is 0.5804 , then 58 percent of independent variables can explain the effect on the dependent variable, the remaining 42 percent is explained by the variable outside the model each year.

3. Tests for dependent variables: coal sales, independent variables: personal income tax article 21, price and exchange rate.

\section{a. Normality test}

JB statistical value 0.204108 with Probability of $0.902981>\alpha=$ $5 \%$, the result of data is normally distributed.

\section{b. Test Multicollinearity}

The VIF value for the variable of personal income tax article 21 $(1,7)$, the price $(2,1)$ and the exchange rate $(2,2)$ of the three variables are no larger than 10, the result is no Multicollinearity in the three independent variables.

\section{c. Test Autocorrelation}

Probability Value F (2.4) or F arithmetic of 0.1021 . Probability Value $\mathrm{F}$ arithmetic $>$ alpha $0.05(5 \%)$, based on the hypothesis test, $\mathrm{H} 0$ is accepted which means no autocorrelation occurs.

d. Test heteroscedasticity

Probability value F arithmetic of $0.1099>$ alpha 0.05 (5\%), based on hypothesis test $\mathrm{H} 0$ accepted which means no heteroscedasticity occur.

\section{e. $F$ test and $t$ Test}

The result of the $\mathrm{F}$ test is $\mathrm{R}$ squared: $0.9558>$ alpha $0.05=$ the model is estimated to be feasible. Result of $t$ test show independent variable that is personal income tax article 21 with result $t$ arithmetic $=10.13121$ while $\mathrm{t}$-table $1.94318, \mathrm{t}$ arithmetic $>\mathrm{t}$ table which statist variable personal income tax article 21 influence to sales variable. personal income tax article 21 income will increase as coal sales increase.

\section{f. Coefficient of determination}

The value of $\mathrm{R}$ squared is 0.9191 , then 91.9 percent of the independent variables can explain the effect on the dependent variable, the remaining 8.1 percent is explained by the variable outside the model. The graph from figure 3 shows the coal sales (PJL) in 2006 to 2015 affecting income of personal income tax article 21 (P21), where the curve of both increases in each year.

4. Tests for dependent variables: coal sales, independent variables: personal income tax article 25/29, price and exchange rate.

\section{a. Normality test}

The statistical value JB 1.067068 with Probability $0.586528>\alpha=$ $5 \%$, the result of data is normally distributed.

\section{b. Test Multicollinearity}

The VIF value for the personal income tax article 25/29 (1.0) variable, the price (1.9) and the exchange rate (2.0) of the three variables are no larger than 10, the result is no Multicollinearity in the three independent variables.

\section{c. Test Autocorrelation}

Probability Value F (2.4) or F arithmetic of 0.4484 . Probability Value $\mathrm{F}$ arithmetic > alpha $0.05(5 \%)$, based on the hypothesis test, H0 is accepted which means no autocorrelation occurs.

\section{d. Test Heteroscedasticity}

Value Probability F arithmetic of $0.2770>$ alpha 0.05 (5\%), based on hypothesis test $\mathrm{H} 0$ accepted which means no heteroscedasticity occur.

\section{e. F test and $t$ Test}

The result of the $\mathrm{F}$ test is $\mathrm{R}$ squared: $0.3355>$ alpha $0.05=$ the model is estimated to be feasible. Result of $t$ test show free variable that is personal income tax article $25 / 29$ with result $t$ arithmetic $=$ 1.126391 while $\mathrm{t}$-table $1.94318, \mathrm{t}$ arithmetic $<\mathrm{t}$ table statistically variable personal income tax article 25/29 no effect to sales of coal.

\section{f. Coefficient of Determination}

The value of $\mathrm{R}$ squared is 0.3140 , then 31 percent of independent variables can explain the effect on the dependent variable, the remaining 69 percent is explained by the variable outside the model. The graph from Figure 4 shows the coal sales coal (PJL) increased in 2006 to 2015 but did not affect personal income tax article 25/29 (P2529), where the curve experienced significant fluctuations.

\section{Conclusion}

Coal sales does not affect the fluctuation of coal price indicated from the result of $t$ test where the value of $t$ arithmetic $<t$ table and R2 $19.5 \%$.

Sales of coal affects royalty income and personal income tax article 21. For royalty to give positive effect to Natural Resources Revenue Sharing Fund in South Sumatera, it is shown from result of $\mathrm{t}$ test, where $\mathrm{t}$ arithmetic $>\mathrm{t}$ table and $\mathrm{R} 258 \%$.

Personal income tax article 21 with $\mathrm{t}$ arithmetic $>\mathrm{t}$ table and R2 91,9\%. This 91.9\% figure shows the positive effect of personal income tax article 21 on Tax Revenue Sharing Fund due to the increasing number of workers from the coal mining industry in South Sumatra. But not with personal income tax article 25/29 where the value of $t$ arithmetic $<t$ table and R2 31\%.

\section{References}

[1] Azwar S., (2016)., Research methods, Issue 3, Print 17

[2] Sunyoto D., (2015)., Consumer behavior and marketing., Print 1., p. 169

[3] Rasul AA., Wijiharjono N., dan Setyowati T., (2013), Microeconomics, Issue 2, p. 112

[4] Sarwono J, (2016), Popular App Analysis Procedures Thesis and Thesis Research Applications with EViews., First Matter, 
p. 31 and 163

[5] Siregar S,. (2015)., Parametric statistics for quantitative research., Issue 3, p. 37

[6] Gujarati D. N., (2007)., Basic econometrics, third edition

[7] Widarjono A., (2007)., Econometrics, theory and application for economics and business., Second edition., Yogyakarta: Econisia Faculty of Economics Islamic University of Indonesia

[8] Sulaksono A., (2015)., The influence of coal production on the economic growth and welfare of society in the era of regional autonomy in Indonesia., Faculty of Economics, University Gunadarma

[9] Ramdhani B., (2015), The influence of selling price and operational cost to net income of coal mining company listed in Indonesia Stock Exchange period 2010 - 2013, Unikom Bandung.

[10] Usman B., (2009), The influence of production volume, export value, and contribution of coal to local revenue and infrastructure progress in Bengkulu Province, University of Bengkulu

[11]Natalia R., (2012)., Internal Control on Non-Tax State Revenues (PNBP) Through the Implementation of Government Regulation No. 9 of 2012 at the Directorate General of Mineral and Coal (Ditjen Minerba) Jakarta, Faculty of Economics, Esa Unggul University

[12] Rahman A,. (2013), Influence of Gross Regional Domestic Product (PDRB) of constant price to Local Original Income (PAD) of Regency of Bintan, Raja Ali Haji Maritime University

[13] Wahyuni, Adi HP., (2009), Growth Analysis and Contribution of Revenue Sharing Funds to Local Income, The 3rd National Conference UKWMS., P. 3

[14] Risal S., Paranoan DB., Djaja S., (2013), Analysis of the Impact of Mining Policy on the Socio-Economic Life of the Community in Makroman Village., EJournal Administrative Reform, 1 (1): 117-131, 2013 